\title{
SISTEM PENUNJANG KEPUTUSAN SELEKSI PELAMAR KERJA PADA BNI LIFE INSURANCE MENGUNAKAN METODE PROFILE MATCHING BERBASIS OBJECT ORIENTED
}

\author{
Dendy Alfiani Satrio ${ }^{1)}$, Lis Suryadi ${ }^{2)}$ \\ ${ }^{1}$ Sistem Informasi, Fakultas Teknologi Informasi, Universitas Budi Luhur \\ 1,2Jl. Raya Ciledug, Petukangan Utara, Kebayoran Lama, Jakarta Selatan 12260 \\ E-mail: dendyalfiani14@gmail.com ${ }^{1)}$, lis.suryadi@budiluhur.ac.id ${ }^{2)}$
}

\begin{abstract}
Abstrak
BNI Life Insurance adalah perusahaan yang menyediakan produk asuransi berupa, asuransi kesehatan, asuransi jiwa, dana pensiun Tujuan BNI Life adalah untuk menyediakan berbagai purnalayanan dan jasa keuangan dan asuransi bagi para nasabahnya. Kebutuhan untuk mendapatkan karyawan baru memang tidak selalu ada namun akan disesuaikan dengan kebutuhan dan pelamar yang melamar kerja setiap ada lowongan pekerjaan itu menjadi masalah juga, sebab harus menyeleksi setiap pelamar tersebut dengan penuh ketelitian, selama ini menentukan pelamar yang diterima untuk dilakukan tahapan test hanya melalui pemeriksaan berkas dokumen administrasi ,dokumen lengkap maka pelamar akan ikut pada tahapan berikutnya. melakukan penilaian administrasi dirasa kurang tepat, ada sebuah metode yang digunakan dalam menyeleksi para pelamar tersebut, untuk itu pada penelitian ini penulis memberikan masukan kepada pihak BNI bahwa menilai palamar sebaiknya menggunakan metode yang digunakan. Tujuan nya penelitian pembuatan sistem penunjang keputusan yang diharapkan dapat menghasilkan calon karyawan yang sesuai kemampuan yang dibutuhkan perusahaan. Penelitian dapat menghasilkan proses penunjang keputusan dengan menggunakan metode Profile Matching. Metode ini menentukan nilai akhir alternatif. Laporan dihasilkan oleh sistem adalah laporan nilai yang berisi ranking dari semua berdasarkan ranking teratas sampai terbawah. Sistem penunjang keputusan ini dibuat dengan menggunakan MySql sebagai database dan Microsoft Visual Studio 2008 sebagai tools sistem.
\end{abstract}

Kata kunci: Sistem Penunjang Keputusan, Metode Profile Matching, Seleksi pelamar kerja, BNI Life Insurance

\section{PENDAHULUAN}

Karyawan merupakan aset terpenting yang dimiliki oleh perusahaan dalam berkembang, kemampuan untuk bersaing serta mendapatkan laba. Persaingan dunia bisnis yang semakin berkembang sehingga perusahaan dapat meningkatkan kualitas perusahaannya. Salah satu upaya yaitu dengan meningkatkan kualitas sumber daya manusia karena sumber daya manusia yang baik dapat meningkatkan produktivitas dan prestasi suatu perusahaan. Kulitas sumber data manusia ditentukan pada

Seleksi pelamar kerja yang berjalan saat ini pada perusahaan yang diteliti yaitu dengan cara melakukan pemeriksan dan penilaian syarat administrasi, dilanjutkan dengan test dan wawancara. Masalah yang dihadapi adalah banyak pelamar maka secara otomatis akan lama juga menyeleksi berkas pelamar tersebut, proses seleksi berkas administrasi dilakukan dengan cara memeriksa berkas satu persatu, ini baru tahapan seleksi berkas, tahapan berikutnya test, masalah yang dihadapi adalah merekap nilai hasil test dilakukan dengan menghitung manual menggunakan kalkulator sehingga sering terjadi kesalahan perhitungan nilai akhir sehingga dapat merugikan pelamar, masalah berikutnya penilaian dengan cara seperti ini dianggap kurang transparan masih terdapat unsur sosial

Berdasarkan uraian permasalahan diatas maka dibutuhkan sistem yang dapat memberikan keputusan dimana dalam nentukan nilai akhir menggunakan sebuah metode yang digunakan pada penelitian ini yaitu profile matching dengan harapan menghasilkan sebuah keputusan yang tepat, dapat mempermudah menentukan pilihan.

Masalah Berdasarkan permasalahan yang dialami oleh BNI Life Insurance. Dalam Seleksi pelamar kerja dapat diidentifikasikan dalam beberapa masalah sebagai berikut:

1) Dalam pengambilan keputusan pelamar terpilih masih sering mengalami keterlambatan dikarenakan membutuhkan waktu yang lama dan masih berdasarkan perkiraan dari pengambil keputusan.

2) Masih terdapatnya subjektifitas dalam pengambilan keputusan karena adanya kedekatan.

3) Penyimpanan berkas yang kurang memadai sehingga sulitnya mencari dokumen lamaran karena penumpukan dokumen yang tidak teratur 
4) Sulitnya mencocokan dan butuh keahlian untuk menentukan kriteria yang dibutuhkan sehingga banyak lamaran yang harus dicek dan dianalisa

\subsection{Tujuan Penulisan}

Dalam penulisan tugas akhir ini penulis memiliki beberapa tujuan, yaitu:

a) Mengidentifikasi proses bisnis serta menganalisa permasalahan yang berkaitan dengan proses pengambilan keputusan seleksi pelamar kerja

b) Merancang model pengambilan keputusan seleksi pelamar kerja dan membuat Sistem Penunjang Keputusan Seleksi pelamar kerja dengan menggunakan metode Profile Matching.

c) Menghasilkan aplikasi Sistem Penunjang Keputusan Seleksi pelamar kerja dan menghasilkan laporan seleksi pelamar kerja

\subsection{Manfaat Penulisan}

Sistem ini membantu pihak-pihak yang terlibat dalam proses pemilihan Pelamar ke tahap selanjutnya dan melakukan perangkingan sesuai bobot yang diperoleh. Sistem ini membantu meningkatkan efisiensi dan efektifitas dalam pengambilan keputusan. Manfaat dari Penulisan Tugas Akhir ini adalah Sistem Penunjang Keputusan Seleksi pelamar kerja akan membantu Bagian SDM dalam melakukan pengambilan keputusan seleksi pelamar kerja yang sesuai dengan kriteria pemilihan serta mengurangi tingkat kesalahan dalam pengambilan keputusan sehingga dapat memberikan hasil maksimal bagi perusahaan. Sistem Penunjang keputusan bukan untuk menggantikan fungsi pengambilan keputusan tetapi akan memudahkan dan membantu Bagian SDM dalam pengambilan keputusan

\section{PENELITIAN TERDAHULU}

Penelitian sejenis dengan judul "Sistem Pendukung Keputusan Pemilihan Personal Homeband Universitas Brawijaya Menggunakan Metode Profile Matching" terdiri dari tiga penulis yaitu Aditya Sudarmadi, Edy Santoso, dan Sutrisno [1] dipublikasikan pada Jurnal Pengembangan Teknologi Informasi Dan Ilmu Komputer, pada tahun 2017 dengan nomor e-ISSN 2548-964X. Permasalahan yang terjadi adalah dalam proses seleksi yang sebelumnya dapat dibilang penilaian yang tidak jelas. Hal ini mengakibatkan waktu yang dibutuhkan untuk mendapatkan personel menjadi lama dan hasil seleksi menjadi subjektif dalam pemilihan, dan juga sangat tidak efisien apabila jumlah pendaftar mahasiswa menjadi banyak, karena sistem seleksi yang sebelumnya menggunakan cara manual. Dengan adanya permasalahan tersebut, maka pihak personal homeband perlu membuat aplikasi sistem penunjang keputusan untuk memudahkan dalam proses pemilihan personal band secara cepat dan tepat. Bahasa pemgoraman yang digunakan di penelitian ini PHP dan MySQL sebagai databasenya.

Penelitian sejenis lainnya dengan judul "Penerapan Metode Profile Matching Pada Proses Pemilihan Lokasi Perumahan” terdiri dari tiga penulis yaitu Muhammad Raihan, Fitriyadi dan Siti Abidah [2] dipublikasikan pada Jurnal Ilmiah Teknik Informatika dan Sistem Informasi (JUTISI), pada tahun 2015 dengan nomor ISSN 2089-3787. Yang menjadi masalah pada penelitian ini yaitu sulitnya menentukan lahan lokasi, apabila kurang teliti dalam pememilihan dapat berakibat lambatnya penjualan, sehingga mengakibatkan keuntungan perusahaan menjadi menurun. Dengan adanya permasalahan tersebut, maka dibutuhkan suatu sistem yang dapat membantu developer dalam memberikan hasil rekomendasi dalam pemilihan lokasi perumahan yang sesuai dengan yang diinginkan developer. Metode profile matching ini dipilih karena metode ini mampu memberikan rekomendasi dengan nilai terdekat, jadi walaupun tidak ada lahan lokasi yang sesuai persis dengan yang di inginkan developer tapi profile matching akan memberikan rekomendasi pemilihan lahan lokasi dengan profil yang terdekat dengan yang diinginkan developer. Bahasa pemgoraman yang digunakan dalam penelitian ini PHP dan MySQL sebagai penyimpanan datanya.

Menurut [3] "Informasi adalah sebuah data yang diolah menjadi data yang lebih bermanfaat dan lebih berguna bagi penerimanya. Sumber informasi adalah sebuah data. Data kenyataan yang mengilustrasikan suatu kejadian-kejadian dan kesatuan nyata. Kejadian-kejadian (event) tersebut adalah kejadian yang ada”.

Menurut [4] "Sistem penunjang keputusan sebagai sistem berbasis computer yang meliputi dari tiga komponen yang saling berhubungan, sistem bahasa (mekanisme untuk komunikasi antara pengguna dengan komponen sistem pendukung keputusan lain), sistem pengetahuan (repositori pengetahuan domain masalah yang terjadi pada sistem penunjang keputusan atau sebagai data), dan sistem proses masalah (hubungan meliputi dua komponen lainnya, terdiri dari satu atau lebih kapabilitas manipulasi pada masalah umum yang digunakan untuk pengambilan keputusan).”.

Menurut [5] "Tujuan dari UML adalah menyediakan sekumpulan bahasa yang dapat digunakan dalam teknik berbasis objek dan teknik pembuatan diagra yang dapat menjadi sebuah gambaran semua model analisa desain”. 
Menurut [6] “Activity diagram merupakan gambaran yang diperoleh dari berbagai aliran aktivitas atau proses bisnis yang terjadi dalam sistem”.

Menurut [7] "profile matching adalah keadaan dimana client dapat mendapatkan hasil yang diinginkan”.

\section{METODE PENELITIAN}

\subsection{Profile Matching}

Metode Profile Matching adalah suatu pengambilan keputusan dengan mengasumsikan terdapat variable predikat yang ideal harus dipenuhi oleh subjek yang diteliti, bukannya tingkat minimal yang harus dipenuhi atau dilewkan.

$$
\text { Xiaohui Liang }
$$

mengungkapkan: "profile matching merupakan hasil dimana client akan mendapatkan hasil yang diharapkan".

Dalam proses Profile Matching, akan dilakukan proses pembandingan antara kompetensi individu kedalam kompetensi standar, sehingga dapat mengetahui perbedaan kompetensinya. Jika nilai gap kecil yang dihasilkan, maka bobot nilainya semakin besar. Karyawan yang memiliki bobot nilai yang besar berarti memiliki peluang yang lebih besar untuk dapat diterima Perushaan berikut:

Prosedur Profile Matching adalah sebagai

1) Menentukan Variabel

Langkah pertama dalam menggunakan Profile Matching adalah menentukan variabel yang nantinya akan digunakan sebagai poin untuk penilaian para Pelamar.

2) Pemetaan GAP.

Gap yang adalah perbedaan nilai aspek dengan nilai target. sebagai Perbedaan nilai profil Pelamar dengan nilai profil ideal.

3) Pembobotan.

Setelah diperoleh gap pada masing-masing Karyawan, setiap profil Karyawan akan diberi nilai sesuai ketentuan pada tabel bobot nilai gap sebagai berikut:

Tabel 1. Bobot GAP

\begin{tabular}{|c|c|c|}
\hline Selinith & $\begin{array}{l}\text { Bcbor } \\
\text { Mrail }\end{array}$ & Ketorargent \\
\hline क & , & 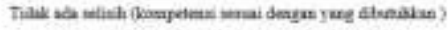 \\
\hline 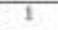 & 25 & 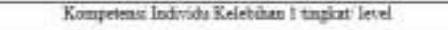 \\
\hline-4 & 4 & 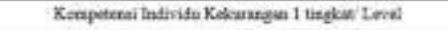 \\
\hline 2 & 35 & 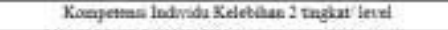 \\
\hline 1 & 3 & 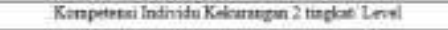 \\
\hline 3 & 23 & 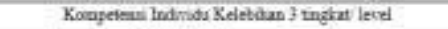 \\
\hline-7 & 7 & 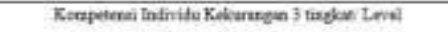 \\
\hline 4 & is & 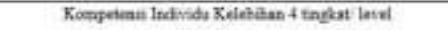 \\
\hline 4 & I & 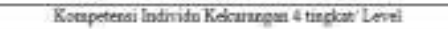 \\
\hline
\end{tabular}

Pada tabel 1 diketahui nilai yang digunakan sesuai dengan selisih dan bobot nilai. Tabel ini berguna untuk panduan pengisian nilai GAP jika selisih 0 maka nilai selisihnya 5. Begitu selanjutnya

4) Perhitungan dan pengelompokan Core Factor

dan Secondary Factor:

Setelah ditentukan hasul dari nilai bobot gap semua aspek sehingga nilai aspek akan di bagi menjadi dua kelompok yaitu kelompok core factor (faktor utama) dan secondary factor (faktor pendukung). Perhitungan core factor dan secondary factor dapat ditunjukkan pada persamaan:

Perhitungan Core Factor

$$
\begin{aligned}
& \mathrm{NCF}=\frac{\sum \mathrm{NC}}{\sum \mathrm{IC}} \\
& \mathrm{NCF}=\text { Nilai core factor } \\
& \mathrm{NC}=\text { Jumlah total nilai core factor } \\
& \mathrm{IC}=\text { Jumlah item core factor }
\end{aligned}
$$

Perhitungan Secondary Factor

$$
\mathrm{NSF}=\frac{\sum \mathrm{NS}}{\sum \mathrm{IS}}
$$

NSF $=$ Nilai secondary factor

NS = Jumlah total nilai secondary factor

IS = jumlah item secondary factor

5) Menentukan presentase Core Factor dan Secondary Factor.

Presentase menentukan Core Factor dan Secondary Factor ditentukan berdasarkan perusahaan.Biasanya presentase yang digunakan untuk menghitung nilai Core Factor lebih besar dari pada presentase yang digunakan untuk menghitung Secondary Factor. disebabkan Core Factor adalah faktor yang paling utama dibandingkan Secondary Factor.Pada umumnya presentase yang akan dipakai adalah 60: 40, sehingga dalam penilaian ini presentase yang digunakan untuk Core Factor adalah 60\% dan untuk Secondary Factor 40\%.

6) Perhitungan nilai total

Menghitung setiap aspek, hitungan nilai berdasarkan perolehan persentase yang di dapat dari core factor dan secondary factor akan diperkirakan berpengaruh terhadap penilaian performa karyawan.

Contoh perhitungan dapat dilihat pada contoh: $\mathrm{N}=(\mathrm{x}) \% . \mathrm{NCF}+(\mathrm{x}) \% . \mathrm{NSF}$

$\mathrm{N}=$ nilai dari aspek

NCF = nilai core factor

$\mathrm{NSF}=$ nilai secondary factor

(x) $\%=$ nilai persen yang diinputkan

7) Perhitungan menentukan Ranking

Hasil proses Profile Matching adalah ranking dari kandidat yang ditunjukan untuk mengisi jabatan 
tertentu di perusahaan. Untuk menentukan ranking karyawan mengacu pada hasil perhitungan yang sudah ditentukan

Contoh perhitungan dapat dilihat pada contoh: $\% . n s$

Rangking $=(\mathrm{x}) \% \cdot n k+(\mathrm{x}) \% \cdot n a+(\mathrm{x}) \% \cdot n \mathrm{n}+(\mathrm{x})$

$\mathrm{Nk}=$ Nilai Kompetensi

$\mathrm{Na}=$ Nilai Administrasi

$\mathrm{Ni}=$ Nilai Interview

$\mathrm{Nk}=$ Nilai Konsistensi

$(\mathrm{X}) \%=$ Nilai persen yang diinputkan

\subsection{Teori Pendukung}

Pengertian Karyawan, Karyawan merupakan salah satu asset perusahaan yang harus dikelola dengan baik. Usaha yang efektif dan efisien mengandung bahwa keluaran yang dihasilkan oleh setiap karyawan dapat memenuhi targetkan yang di harapkan oleh perusahaan. Jumlah hasil kerja yang mampu di selesaikan oleh setiap karyawan, dapat diketahui berapa jumlah karyawan yang sesungguhnya diperlukan oleh perusahaan untuk mencapai target (Novera, 2010).

\subsection{Metode Pengumpulan Data}

a. Observasi

Kegiatan ini dilakukan untuk mengumpulkan data dengan cara pengamatan langsung dengan halhal yang berkaitan dengan sistem penunjang keputusan seleksi pelamar kerja sekaligus sebagai masukan dalam penelitian ini

b. Wawancara

Wawancara merupakan proses pengumpulan data dengan bertatap muka langsung dengan mengajukan pertanyaan yang berhubungan dengan seleksi pelamar kerja yang dilakukan pada bagian Human Capital \& Employee Training sebagai pihak yang diberikan wewenang untuk menyelenggarakan seleksi pelamar kerja. Dari wawancara tersebut, penulis juga mendapatkan dokumen yang akan digunakan dalam pengembangan sistem penunjang keputusan seleksi pelamar kerja

c. Analisa Dokumen

Analisa dokumen merupakan cara untuk mendapatkan informasi yang sesuai sistem berjalan , okumen akan di analisa untuk sistem yang akan dibuat. Agar dapat menganalisa dokumen, maka perlu meminta dokumen yang berkaitan dengan pembuatan sistem penunjang keputusan

d. Studi Pustaka

Kegiatan ini dilakukan dengan mengumpulkan dan membaca referesi seperti buku-buku, artikel, jurnal/prosiding atau dokumen lain yang telah dipublikasi, serta literature tugas akhir yang berkaitan dengan sistem penunjang keputusan dan profil matching

e. Kuesioner
Kuesioner dilakukan pada bagian Human Capital \& Employee Training di BNI Life Insurance. untuk menentukan core factor dan secondary factor serta nilai target yang telah ditentukan yang akan digunakan untuk pengembangan sistem penunjang keputusan seleksi pelamar kerja

\section{HASIL DAN PEMBAHASAN}

\subsection{Analisa Masalah}

Dalam analisa suatu masalah pada pengambilan keputusan proses, yang ditentukan pelamar pada BNI Life Insurance, penulis menggunakan Fishbone Diagram untuk analisa masalah, seperti pada gambar kemudian bisa di identifikasi masalah yang ada

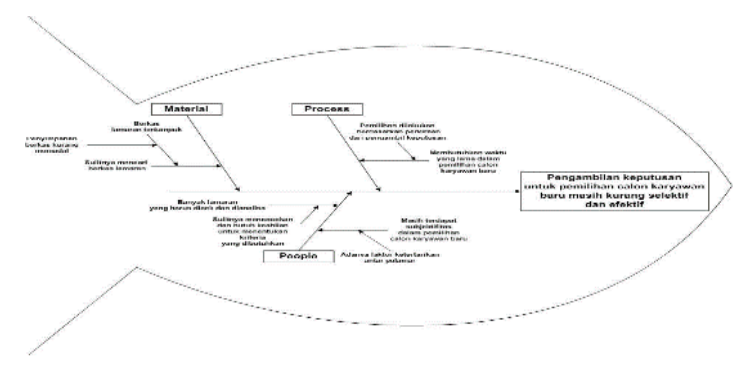

Gambar 1. Fishbone

\subsection{Kriteria yang di butuhkan}

Kriteria dan subkriteria yang digunakan untuk menentukan nilai karyawan seperti tabel 4

Tabel 2. Ketentuan Kriteria

\begin{tabular}{ll}
\hline Kode Kriteria & Nama Kriteria \\
\hline KRT-1 & Kompetensi \\
KRT-2 & Administrasi \\
KRT-3 & Interview \\
KRT-4 & Konsistensi \\
\hline
\end{tabular}

\subsection{Bobot Kriteria}

Bobot kriteria yang dibutuhkan untuk pengambilan keputusan penentuan pelamar pada BNI Life Insurance . penilaian kriteria yang sudah ditentukan dapat dilihat pada table berikut:

Tabel 3. Presentase Bobot Kriteria

\begin{tabular}{ll}
\hline Nama Kriteria & Bobot \\
\hline Kompetensi & $40 \%$ \\
Administrasi & $15 \%$ \\
Interview & $15 \%$ \\
Konsistensi & $30 \%$ \\
\hline
\end{tabular}

\subsection{Target Subkriteria}

Berdasarkan hasil wawancara, penilaian dan subkriteria dari nilai target yang sudah ditentukan core factor dan secondary factor untuk menenntuan pelamar pada BNI Life Isnurance. pada tabel berikut. 
Tabel 4. Nilai Target Setiap Subkriteria

\begin{tabular}{|c|c|c|c|c|}
\hline Kriteria & $\begin{array}{l}\text { Kode Sub } \\
\text { Kriteria }\end{array}$ & Nama Sub Kriteria & $\begin{array}{l}\text { Nilai } \\
\text { Target }\end{array}$ & Status \\
\hline \multirow{2}{*}{$\begin{array}{l}\text { Kompetensi } \\
(40 \%)\end{array}$} & SKRT-1 & Pengalaman & 5 & $\mathrm{CF}$ \\
\hline & SKRT-2 & Skill & 5 & $\mathrm{CF}$ \\
\hline \multirow{2}{*}{$\begin{array}{l}\text { Administrasi } \\
(15 \%)\end{array}$} & SKRT-3 & Jurusan & 4 & SF \\
\hline & SKRT-4 & IPK & 4 & SF \\
\hline \multirow{2}{*}{$\begin{array}{l}\text { Interview } \\
(15 \%)\end{array}$} & SKRT-5 & Prilaku & 5 & $\mathrm{CF}$ \\
\hline & $\begin{array}{l}\text { SKRT-6 } \\
\text { SKRT-7 }\end{array}$ & $\begin{array}{l}\text { Loyalitas } \\
\text { Kesiapan Kerja }\end{array}$ & $\begin{array}{l}5 \\
5\end{array}$ & $\begin{array}{l}\mathrm{CF} \\
\mathrm{CF}\end{array}$ \\
\hline \multirow{3}{*}{$\begin{array}{l}\text { Konsistensi } \\
(30 \%)\end{array}$} & SKRT-8 & Ketelitian & 5 & $\mathrm{SF}$ \\
\hline & SKRT-9 & Kepribadian & 4 & $\mathrm{CF}$ \\
\hline & SKRT-10 & Kerapihan & 5 & SF \\
\hline
\end{tabular}

\subsection{Nilai Aspek}

Untuk nilai aspek sub kriteria dari kriteria pada table 5:

Tabel 5. Nilai Aspek Subkriteria

\begin{tabular}{ll}
\hline Nilai Aspek & Keterangan \\
\hline 1 & Sangat Kurang \\
2 & Kurang \\
3 & Cukup \\
4 & Baik \\
5 & Sangat baik \\
\hline
\end{tabular}

\subsection{Hasil Perhitungan}

Berikut hasil penilaian pelamar yang telah di input dapat dijelaskan melalui tabel 6 berikut:

Tabel 6. Perhitungan Nilai Gap Performance

\begin{tabular}{lllllll}
\hline $\begin{array}{l}\text { Kode } \\
\text { Pelamar }\end{array}$ & \multicolumn{2}{l}{ Kode Subkriteria } & & \\
\cline { 2 - 7 } & $\begin{array}{l}\text { Nilai } \\
\text { SKRT- } \\
\text { 1(Pengala } \\
\text { man) }\end{array}$ & $\begin{array}{l}\text { Nilai } \\
\text { Target }\end{array}$ & Gap & $\begin{array}{l}\text { Nilai } \\
\text { SKRT- } \\
\text { 2(Skill) }\end{array}$ & $\begin{array}{l}\text { Nilai } \\
\text { Target }\end{array}$ & Gap \\
\hline P001 & 5 & 5 & 0 & 3 & 5 & -2 \\
P002 & 4 & 5 & -1 & 5 & 5 & 0 \\
P003 & 4 & 5 & -1 & 4 & 5 & -1 \\
P004 & 5 & 5 & 0 & 5 & 5 & 0 \\
P005 & 3 & 5 & -2 & 4 & 5 & -1 \\
\hline
\end{tabular}

Setelah hasil didapat, kemudian penjelasan tabel 9 merupakan hasil hitungan CF \& SF

Tabel 7. Perhitungan dan Pengelompokan Aspek Kompetensi

\begin{tabular}{llllll}
\hline $\begin{array}{l}\text { Kode } \\
\text { Pelamar }\end{array}$ & \multicolumn{2}{l}{ Core Faktor(60\%) } & \multicolumn{2}{l}{$\begin{array}{l}\text { Secondary } \\
\text { Factor(40\%) }\end{array}$} & Total \\
\hline P001 & 4,00 & 2,40 & 0,00 & 0,00 & 2,40 \\
P002 & 4,50 & 2,70 & 0,00 & 0,00 & 2,70 \\
P003 & 4,00 & 2,40 & 0,00 & 0,00 & 2,40 \\
P004 & 5,00 & 3,00 & 0,00 & 0,00 & 3,00 \\
P005 & 3,50 & 2,10 & 0,00 & 0,00 & 2,10 \\
\hline
\end{tabular}
Pelamar

Tabel 8 menerangkan hasil perangkingan

Tabel 8. Penentuan Rangking pada pelamar

\begin{tabular}{lllllll}
\hline $\begin{array}{l}\text { Kode } \\
\text { Pelamar }\end{array}$ & Kriteria & & & & Total & $\begin{array}{l}\text { Ranki } \\
\text { ng }\end{array}$ \\
\cline { 2 - 7 } & $\begin{array}{l}\text { Performa } \\
\text { nce(40) }\end{array}$ & $\begin{array}{l}\text { SOP } \\
\mathbf{( 3 0 )}\end{array}$ & $\begin{array}{l}\text { KPI } \\
\mathbf{( 1 5 )}\end{array}$ & $\begin{array}{l}\text { Absen } \\
\text { si(30) }\end{array}$ & & \\
\hline P001 & 0,96 & 0,3 & 0,45 & 1,35 & 3,06 & 4 \\
P002 & 1,08 & 0,3 & 0,39 & 1,35 & 3,12 & 3 \\
P003 & 0,96 & 0,3 & 0,45 & 1,5 & 3,21 & 2 \\
P004 & 1,2 & 0,24 & 0,36 & 1,5 & 3,3 & 1 \\
P005 & 0,84 & 0,27 & 0,42 & 1,35 & 2,88 & 5 \\
\hline
\end{tabular}

\subsection{Perancangan Sistem}

Bentuk dari perancangan di mulai dari input data kriteria, subkriteria, Pelamar seperti dijelaskan di gambar 1

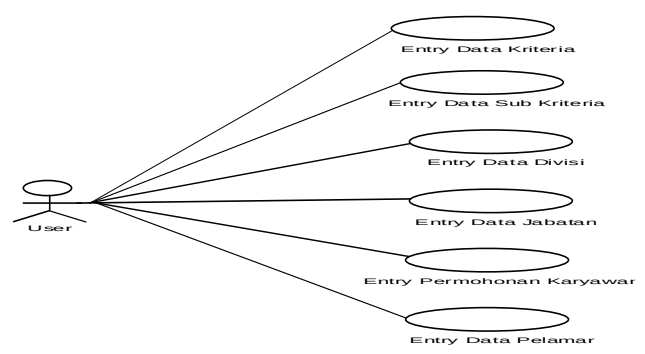

Bentuk dari Entity Relationship Diagram (ERD) yang di hasilkan seperti di jelaskan di gambar 2

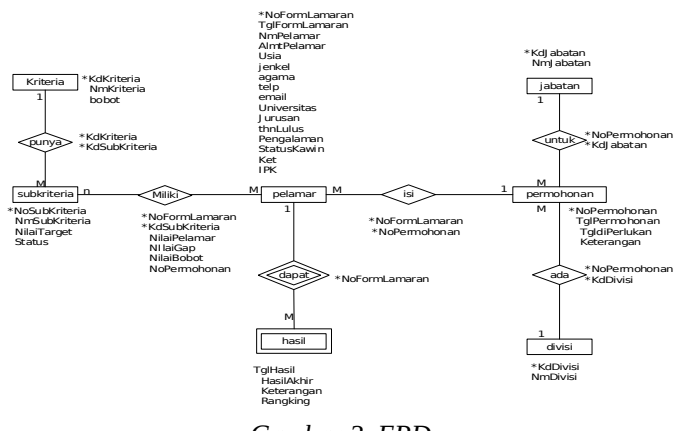

Class Diagram yang di hasilkan di jelaskan dalam gambar 3 


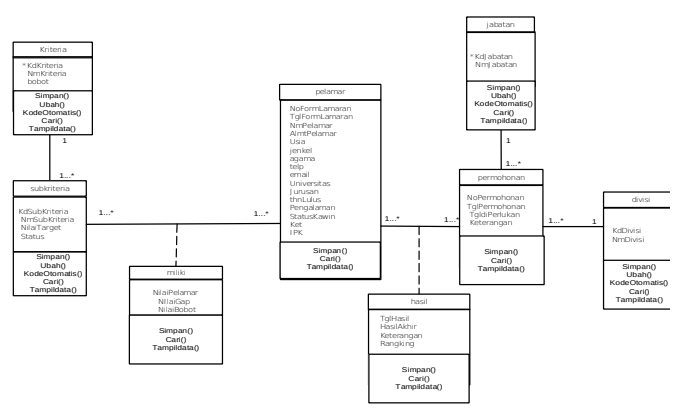

\subsection{Rancangan Basis Data}

Spesifikasi basis data merupakan rinci tentang tiap tabel. Berikut contoh Spesifikasi basis data yang digunakan untuk Pelamar Karyawan Pada BNI Life Insurance.

1) Nama File: Kriteria

Primary Key: kdkriteria

Struktur:

Tabel 9. Tabel Kriteria

\begin{tabular}{llllll}
\hline No & Nama Field & Jenis & Lebar & Desimal & Keterangan \\
\hline 1 & kdkriteria & Varchar & 5 & - & Kode Kriteria \\
2 & nmkriteria & Varchar & 50 & - & Nama Kriteria \\
3 & bobot & Integer & 3 & - & Bobot Kriteria \\
\hline
\end{tabular}

Tabel kriteria berfungsi untuk menyimpan data kriteria pelamar yang digunakan pada saat perhitungan pelamar terbaik.

2) Nama File: Pelamar

Primary Key: NoFormLamaran

Struktur:

Tabel 10. Tabel Pelamar

\begin{tabular}{lllll}
\hline No Nama Field & Jenis & \multicolumn{3}{c}{ Lebar } \\
\hline 1 & NoFormLamaran & Varchar 4 & - & Kode Pelamar \\
2 & nmPelamar & Varchar 25 & - & Nama Pelamar \\
3 & AlmtPelamar & Varchar 50 & - & Alamat \\
4 & TelpPelamar & Varchar 12 & - & No Telpon \\
5 & Email & Vachar 25 & - & E-mail \\
\hline
\end{tabular}

Tabel Pelamar berfungsi untuk menyimpan hasil yang akan dinilai.

\subsection{Rancangan Sistem}

Berikut Tampilan menu utama dari rancangan Keputusan Seleksi Pelamar BNI Life Insurance a. Menu Utama

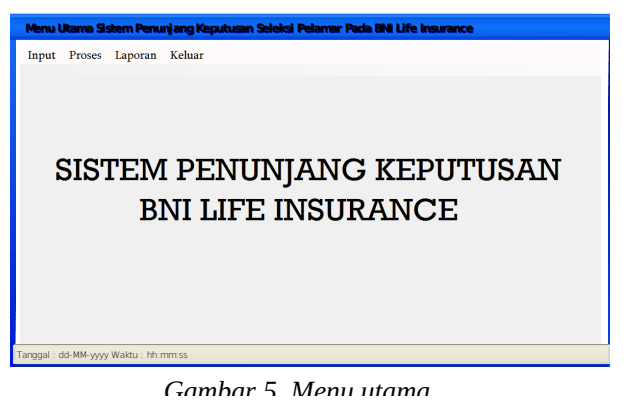

Pada gambar layar Menu Utama akan menampilkan seluruhan proses yang terjadi pada Seleksi Karyawan, masing-masing fungsi akan dikelompokan sesuai kebutuhan file master data dipilih maka akan muncul kebutuhan file master data.

b. Entry Data Kriteria

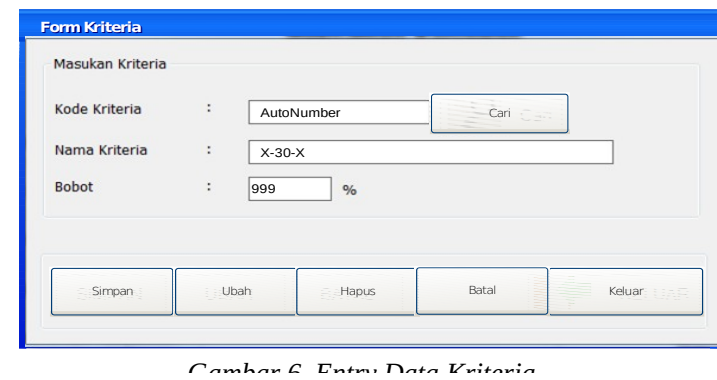

Pada gambar rancangan Data Kriteria muncul data yang telah di input kedalam database. Terdapat tombol untuk menambahkan data Kriteria, tombol ubah untuk mengubah data kriteria.

c. Proses Perhitungan dan Algoritma Profile Matching

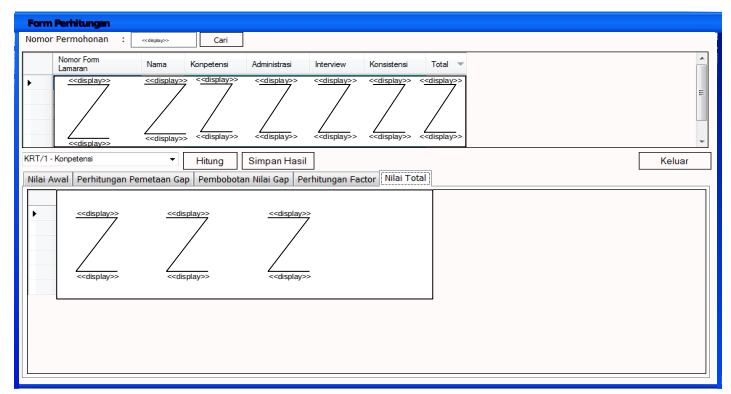

Gambar 7. Proses Profile Matchina

Pada hasil perhitungan maka akan tampil keseluruhan proses dan muncul perangkingan.

d. Laporan Pelamar 


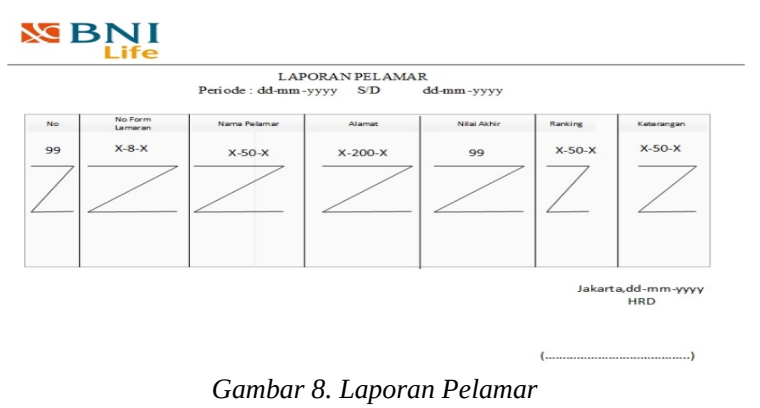

e. Laporan Rekapitulasi Pelamar

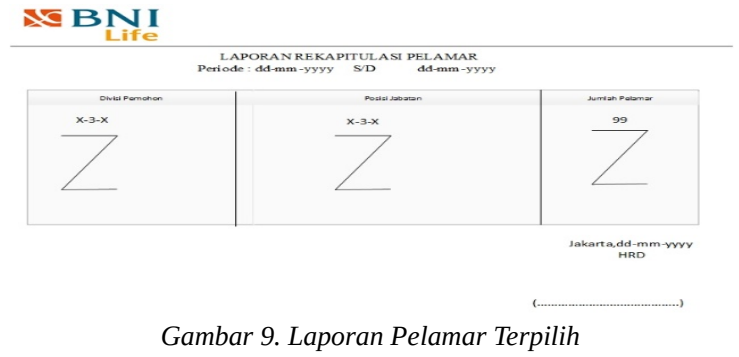

\section{KESIMPULAN}

Berdasarkan penelitian yang dilakukan pada BNI Life Insurance. maka dapat ditarik kesimpulan sebagai berikut:

a. Dengan Sistem Penunjang Keputusan dengan metode profile matching ini dapat mempercepat proses pemilihan pelamar kerja karena perhitungan dilakukan oleh sistem sehingga akan mengurangi keterlambatan dalam pengambilan keputusan.

b. Sistem Penunjang Keputusan ini dapat membantu dan menghindari adanya subjektifitas yang mungkin terjadi dalam pengambilan keputusan yang selama ini masih memungkinkan terjadi di dalam perusahaan.

c. Penyimpanan data sudah komputerisasi, sehingga data selalu ada jika dibutuhkan kapanpun dan adanya kemudahan dalam pencarian data.

d. Dengan adanya sistem pengambilan keputusan ini maka dapat mempermudah pengambilan keputusan sesuai dengan syarat dan kriteria yang telah ditentukan sehingga lebih efektif, cepat, dan efisien.

\section{DAFTAR PUSTAKA}

[1] Aditya Sudarmadi, Edy Santoso, Sutrisno, "Sistem Pendukung Keputusan Pemilihan Personal Homeband Universitas Brawijaya Menggunakan Metode Profile Matching”. Jurnal Pengembangan Teknologi Informasi Dan Ilmu Komputer vol 1, no. 12, 2017.

[2] Muhammad Raihan, Fitriyadi, Siti Abidah, "Penerapan Metode Profile Matching Pada Proses
Pemilihan Lokasi Perumahan”. JUTISI, vol 4, no. 3, 2015.

[3] Jeperson Hutahean, "Konsep Sistem Informasi". Yogyakarta: Deepublish, 2015.

[4] Dicky Nofriansyah, "Sistem Pendukung Keputusan”. Medan: STMIK Tri Guna Dhargma, 2016.

[5] Alan Dennis, Barbara Haley Wixom, David Tegarden, "Systems Analysis Design UML . New Jersey: Wiley, 2012.

[6] Rosa Ariani Sukamto, Muhammad Sahalahuddin, "Rekayasa Perangkat Lunak Terstruktur Dan Berorientasi Objek”.Bandung: Informatika, 2014.

[7] Xiaohui Liang, "Security And Privacy In Mobile Social Networks”. London: Heidelberg Dordrecht, 2013. 